\title{
Importance of Educating Girls for the Overall Development of Society: A Global Perspective
}

\author{
Tabreek Somani \\ Aga Khan Academy, Mombasa
}

\begin{abstract}
Educating girls is pivotal to the development of society. Despite many global declarations and development goals, and significant effort by the international community, gender disparity in education continues to exist. This article focuses on the first research question of Somani's (2017) study titled "Girls Have a Right to Education Too" to better understand the importance and impact of educating girls and increase awareness. This qualitative research uses primary data from 38 respondents comprising 29 interviewees and nine participants in a focus group. Participants included 16 experts and leaders in academia and development, 13 educators, four students, three development professionals, and two parents. This broad spectrum of individuals provided real-life perspectives and contextual information for the findings and recommendations of the study. Contrary to some of the earlier studies, particularly in remote and rural contexts, this study reaffirmed the importance and vital impact of educating girls for the overall development of society and proposes various strategies to increase awareness and reduce gender disparity in education. The proposed strategies include: mentorship programs, summer projects, community service initiatives, training of educators, community engagement, and context-specific media campaign including effective use of social media.
\end{abstract}

Keywords: girls' education, gender equality, awareness, impact, human rights, human capabilities, sustainable development

\section{Introduction}

A famous African proverb apprises us, "If you educate a man, you educate an individual, but if you educate a woman you educate a family (nation)" (Suen, 2013, p. 61). I personally witnessed the innate potential of the girls to develop and contribute to the society as part of my community service group. As an organizing member of the Learn and Earn community service group, I taught young girls how to cook new varieties of low-cost, affordable dishes to support their families in Kenya. During our interactions, I observed how they were able to unleash their potential and excel given the right opportunity. They have the ability to play a key role in the development of society while taking care of their families. I strongly believe that education is a key driver for their development. "A dollar invested in an additional year of schooling generates $\$ 10$ in benefits in low-income countries" (International Commission on Financing Global Education Opportunity, 2015, p. 14).

I would like to put on record my deep gratitude to each individual and institution whose support and valuable input enabled me to complete my research study titled "Girls Have a Right to Education Too." Special thanks to the Aga Khan Academy Mombasa, my supervisor, my mentors, interviewees, questionnaire respondents, and focus group participants. I would also like to thank and acknowledge the editorial support provided by my mom, Salima Somani. Thank you all! 
In addition to my personal experience, I am inspired by the various works of development organizations including the Aga Khan Development Network, United Nations, and the Malala Fund, among others to promote girls' education. I truly believe that girls can perform at the highest potential given the right opportunity. Educating girls has a far-reaching effect on sustainable development (Bhagavatheeswaran et al., 2016) and girls should have an equal right to quality education (Jones, 2011; United Nations Educational, Scientific, and Cultural Organization [UNESCO], 2014). Table 1 presents some of the key benefits of educating girls.

Table 1. Benefits of Educating Girls

\begin{tabular}{|c|c|c|}
\hline For Themselves & For Families & For Communities and Countries \\
\hline $\begin{array}{l}\text { Women's earnings increase by } \\
10 \% \text { through additional year of } \\
\text { schooling }\end{array}$ & $\begin{array}{l}\text { A child of a literate mother is } \\
50 \% \text { more likely to live past } 5 \\
\text { years of age }\end{array}$ & $\begin{array}{l}\text { Investing in girls' education in } \\
\text { Sub-Saharan Africa can boost } \\
\text { agricultural output by } 25 \%\end{array}$ \\
\hline $\begin{array}{l}\text { Girls with secondary schooling } \\
\text { are } 6 \text { times less likely to marry } \\
\text { as children }\end{array}$ & $\begin{array}{l}12.2 \text { million children could } \\
\text { avoid becoming stunted if } \\
\text { their mothers had a secondary } \\
\text { education }\end{array}$ & $\begin{array}{l}35 \% \text { higher gross domestic } \\
\text { product per capital is associated } \\
\text { with each additional year of } \\
\text { education }\end{array}$ \\
\hline
\end{tabular}

Note. Source: Global Partnership for Education (2016).

\section{International Commitments and Declarations}

United Nations (UN) organizations aim to enforce basic human rights including education for all. Article 26 (1) of the Universal Nations Declaration of Human Rights stated,

Everyone has the right to education. Education shall be free, at least in the elementary and fundamental stages. Elementary education shall be compulsory. Technical and professional education shall be made generally available and higher education shall be equally accessible to all on the basis of merit. (UN, 1948)

Ever since, declarations and treaties have been promulgated to transform these ambitions into reality. The International Bill of Human Rights contains provisions on compulsory and free primary education and on nondiscrimination in education (UN General Assembly, 1948). The Convention on the Elimination of All Forms of Discrimination Against Women (UN General Assembly, 1979) and Convention on the Rights of the Child (UN General Assembly, 1989) contain the most comprehensive set of legally enforceable commitments concerning both rights to education and to gender equality. The Jomtien Declaration (UNESCO, 1990), Dakar Framework for Action (UNESCO, 2000b), and Millennium Development Goals (MDGs; UN, 2000) go substantially beyond the human rights treaties in their coverage. They call for early childhood care and education, learning programs for all young people and adults, and improvement in the quality of education, while the Dakar Framework for Action and MDGs also include time-bound targets.

The commitment to gender equality in the Dakar framework for action included

Goal 2: ensuring that by 2015 all children, particularly girls... have access to, and complete, free and compulsory education of good quality; Goal 4: achieving a 50\% improvement in levels of adult literacy by 2015, especially for women; Goal 5: eliminating gender disparities in primary and secondary education by 2005 , and achieving gender equality in education by 2015 , with a focus on ensuring girls' full and equal access to, and achievement, in basic education. (UNESCO, 2000b, p. 8) 
The commitment to gender equality in MDG (UN, 2000) included (a) Goal 2: achieving universal primary education - Target 3: ensure that, by 2015, children everywhere, boys and girls alike, will be able to complete a full course of primary schooling and (b) Goal 3: promote gender equality and empower women - Target 4: eliminate gender disparity in primary and secondary education, preferably by 2005, and to all levels of education no later than 2015 .

The Asia and Pacific Regional Framework for Action, adopted by the Asia-Pacific Conference on Education for All 2000 Assessment (held in Bangkok on January 17-20, 2000) stated,

It is essential to eliminate systemic gender disparities, where they persist, amongst girls and boys, throughout the education system - in enrolment, achievement and completion; in teacher training and career development; in curriculum, and learning practices and learning processes. This requires better appreciation of the role of education as an instrument of women's equality and empowerment. (UNESCO, 2000a, p. 100)

The recently adopted sustainable development goals reaffirm the world's commitment to achieving equitable quality education for all, gender equality, and empowerment of women and girls by 2030 (UN Development Programme, 2015). The achievement of these goals will require substantial resources, political will, and persistent and coordinated efforts by all stakeholders.

\section{Current State of Gender Equality in Education}

There has been some progress, and girls' proportion of primary school-age children out of school has reduced from $58 \%$ in 2000 to $52 \%$ in 2015 . However, girls are still at a disadvantage, particularly in Sub-Saharan Africa, the Arab States, and South and West Asia (UNESCO Institute for Statistics, 2016). Despite improvements in school enrollment rates for girls in developing countries, they continue to be excluded from the education system (United Nations Children's Fund [UNICEF], 2015).

Despite growing evidence of the impact and importance of educating girls, a large segment of our society, particularly in developing countries, takes little to no action to educate the critical population. Two thirds of the illiterate adult population in the world are women; over 63 million girls around the world are out of school (UNESCO Institute for Statistics, 2016), and 47\% of the out-ofschool girls are never expected to enroll as compared to $35 \%$ of boys (UNESCO, 2016). As presented in Table 2, 69\% of low-income countries are still to achieve gender parity in primary education, $91 \%$ in lower secondary education, and 95\% in upper secondary education (UNESCO, 2016).

Table 2. Gender Parity Index (GPI) of Enrollment Rates by Income Group (2014)

\begin{tabular}{lcccccc}
\hline & \multicolumn{2}{c}{ Primary } & \multicolumn{2}{c}{ Lower Secondary } & \multicolumn{2}{c}{ Upper Secondary } \\
\cline { 2 - 7 } & GPI & $\begin{array}{c}\text { Countries } \\
\text { With Parity }\end{array}$ & GPI & $\begin{array}{c}\text { Countries } \\
\text { With Parity }\end{array}$ & GPI & Countries \\
& 0.99 & $63 \%$ & 0.99 & $46 \%$ & 0.98 & $23 \%$ \\
World & 0.93 & $31 \%$ & 0.86 & $9 \%$ & 0.74 & $5 \%$ \\
Low income & 1.02 & $52 \%$ & 1.02 & $33 \%$ & 0.93 & $17 \%$ \\
Lower middle income & 0.97 & $70 \%$ & 1.00 & $60 \%$ & 1.06 & $22 \%$ \\
Upper middle income & 1.00 & $81 \%$ & 0.99 & $59 \%$ & 1.01 & $37 \%$ \\
High income & & & & & &
\end{tabular}

Note. Source: UNESCO (2016, p. 262). 
In most societies, women do not enjoy the same opportunities as men. Their life choices and chances are more restricted than those of men. Girls' unequal access to and performance in education is both a cause and a consequence of these disparities. Educational inequality is a major contravention of girls'/women's rights and an impediment to social and economic development. Dr. Mahbub-ul-Haq asserted that "human development, if not engendered, is endangered" (UN Development Programme, 1995, p.1).

\section{Purpose of the Study and Research Question}

Considering the current state of gender disparity in education, I undertook an in-depth study of the problem. This issue has been around for many decades and is still unresolved despite being identified as a key challenge by the international community. The aims of my study were to better understand the importance and impact of educating girls, explore gender disparity in education and key obstacles to girls' education, and propose strategies to reduce inequalities and increase awareness (Somani, 2017). This article focuses on the research question, "What is the importance and impact of educating girls?" and suggests strategies to increase awareness about the importance and impact of educating girls. As part of my study, I spoke to a number of stakeholders, including international experts and leaders in academia and development to seek their perspectives on this issue. My target audience is policy makers, educators, and development professionals.

\section{Research Methodology}

This qualitative study was designed to include a variety of primary and secondary sources. Primary sources included interviews and a focus group, which are very effective and the most commonly used methods for qualitative research (Savin-Baden \& Major, 2013). Secondary sources included journals, online articles, and reports. The first section of the open-ended interview questionnaire dealt with the importance and impact of educating girls.

A purposive sampling method was used to select the study participants, who included education experts from different parts of the world and students, parents, and educators from developing countries. Purposive sampling is mostly used in qualitative research to explicitly select participants who would provide appropriate data (Green \& Thorogood, 2004). Selecting experts with knowledge and experience in the field of education and development, in developing countries, provided an excellent resource pool to capture and analyze their ideas and thoughts for the study as well as potential solutions. Overall, the purposive sampling approach provided contextual information based on real-life perspective that was critical to informing the study findings and recommendations.

Verbal consent was received from study participants, and permission was acquired to record their interviews and the focus group. Confidentiality of data was maintained and assured to study participants. I conducted interviews and made sure that privacy was provided to the participants at that time. The interviews and the questionnaire were in English, as all participants had good English language skills. The focus group was conducted to explore diversity of opinions and differences in perspectives of educators.

The total number of study respondents was 38, comprising 29 interviewees and nine participants in a focus group. Participants included 16 experts and leaders in academia and development, 13 educators, four students, three development professionals, and two parents. This broad spectrum of individuals enabled me to understand the viewpoints of different stakeholders for study findings and recommendations. Table 3 presents a summary of research methods, and Table 4 displays the profile of study participants. 
Table 3. Summary of Research Methods ( $\mathrm{n}=38$ )

\begin{tabular}{lc}
\hline Method & Participants \\
\hline Interview & 29 \\
In-person or online & 8 \\
Recorded or written responses with follow-up & 21 \\
Focus group & 9 \\
\hline
\end{tabular}

Table 4. Profile of Study Participants

\begin{tabular}{lcccccc}
\hline & Total & Female & Africa & $\begin{array}{c}\text { Central/South } \\
\text { Asia }\end{array}$ & $\begin{array}{c}\text { North } \\
\text { Europe }\end{array}$ & America \\
\hline Experts/leaders & 16 & $50 \%$ & 1 & 9 & 3 & 3 \\
Educators & 13 & $85 \%$ & 10 & 2 & - & 1 \\
Students & 4 & $75 \%$ & 2 & 2 & - & - \\
Development professionals & 3 & $67 \%$ & - & 1 & - & 2 \\
Community members & 2 & $100 \%$ & 1 & 1 & - & - \\
Total $^{\text {a }}$ & 38 & $68 \%$ & 14 & 15 & 3 & 6 \\
\hline
\end{tabular}

Note. Age range $=16-78$ years (average $=42$ ).

a All selected experts/leaders, educators, and development professionals from Europe and North America had knowledge and experience in the field of education and development and had worked or were currently working in developing countries.

All interviews, both individual and focus group, were recorded and transcribed. Based on critical review, the data were analyzed to identify similarities, differences and emerging themes to inform findings and recommendations. NVivo, qualitative data analysis software, was also used for coding and analyzing the interview responses to organize them into relevant themes.

\section{Framework}

Education can improve capabilities of a person, and that person can bring positive social change in society (Andrés \& Chavez, 2015). The framework of the study is derived from the human rights model, human capabilities approach, and awareness about girls' education.

The human rights model was developed by UNESCO and UNICEF. This rights-based approach declares that every human being, including every child, is entitled to receive an education, even when one cannot be sure that this education will pay off in human capital terms. Every child should get access to quality education with dignity and respect, and without discrimination (UNICEF, 2007).

The focus of the human capabilities approach is to enable individuals to lead lives they can value and have sufficient choices to make that life for themselves. Sen (1997) described the role of the human capabilities approach as facilitating personal well-being, freedom and influencing social change and economic development. 


\section{Study Findings}

This section presents the infographics summary of research findings, followed by synthesis and participant quotes on the rights-based approach, human capabilities approach, and awareness about girls' education. The percentages in Figure 1 represent frequency of responses by study participants. For example, $100 \%$ of the participants felt that education is a fundamental human right and improves gender equality, and 3\% (mostly men) felt that it provides effective resistance to domestic violence.

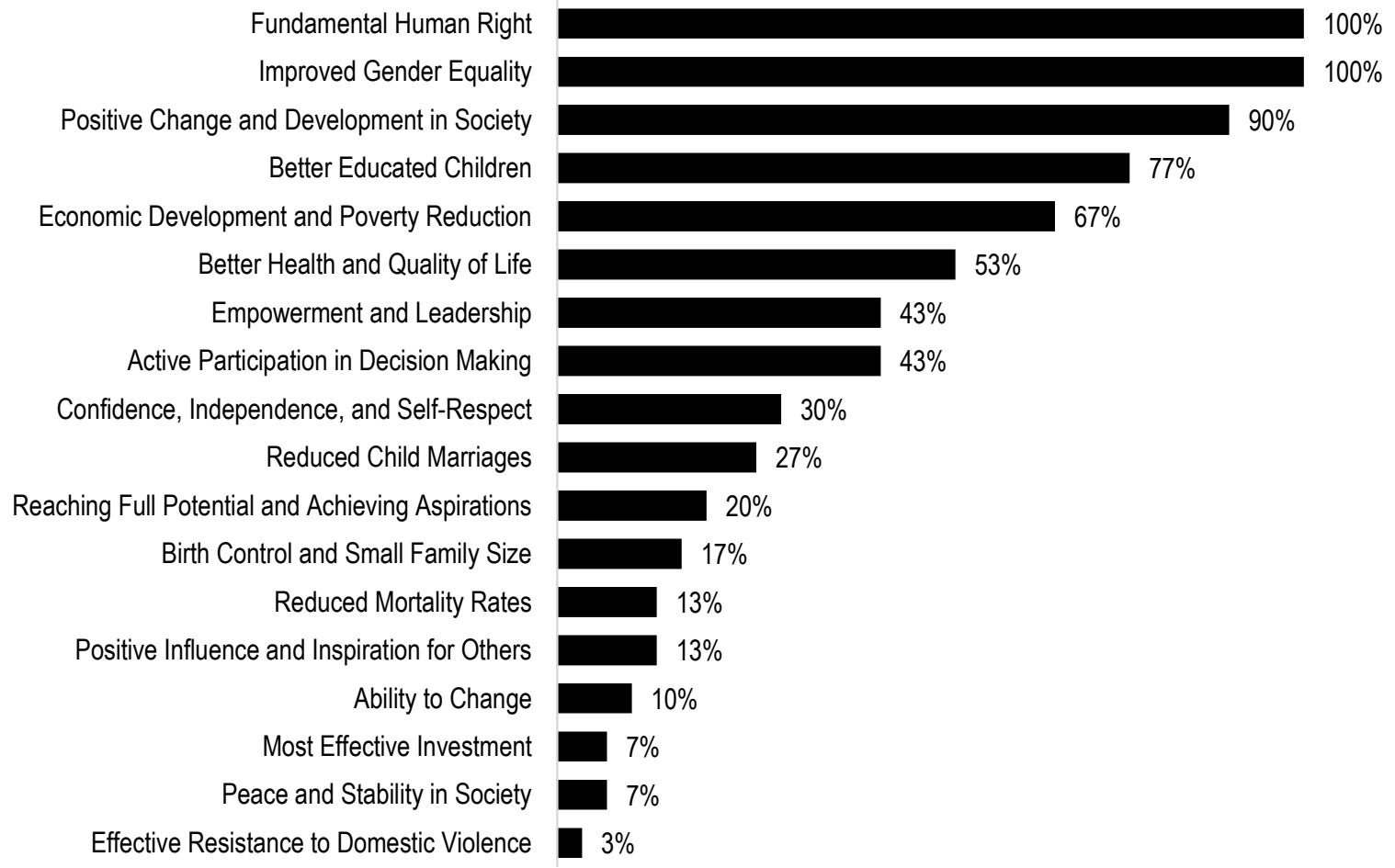

Figure 1. Importance and Impact of Educating Girls 
Figure 2 presents factors responsible for the lack of awareness identified by the study participants. Forty percent of study participants (mostly women) reported a lack of awareness, whereas 30\% (mostly men) were of the view that the level of awareness is uneven in different regions. Twenty percent (mostly women) were of the view that awareness is increasing but there is still a gap, and $10 \%$ (mostly women) felt that there is adequate awareness and the gender disparity is due to other barriers.

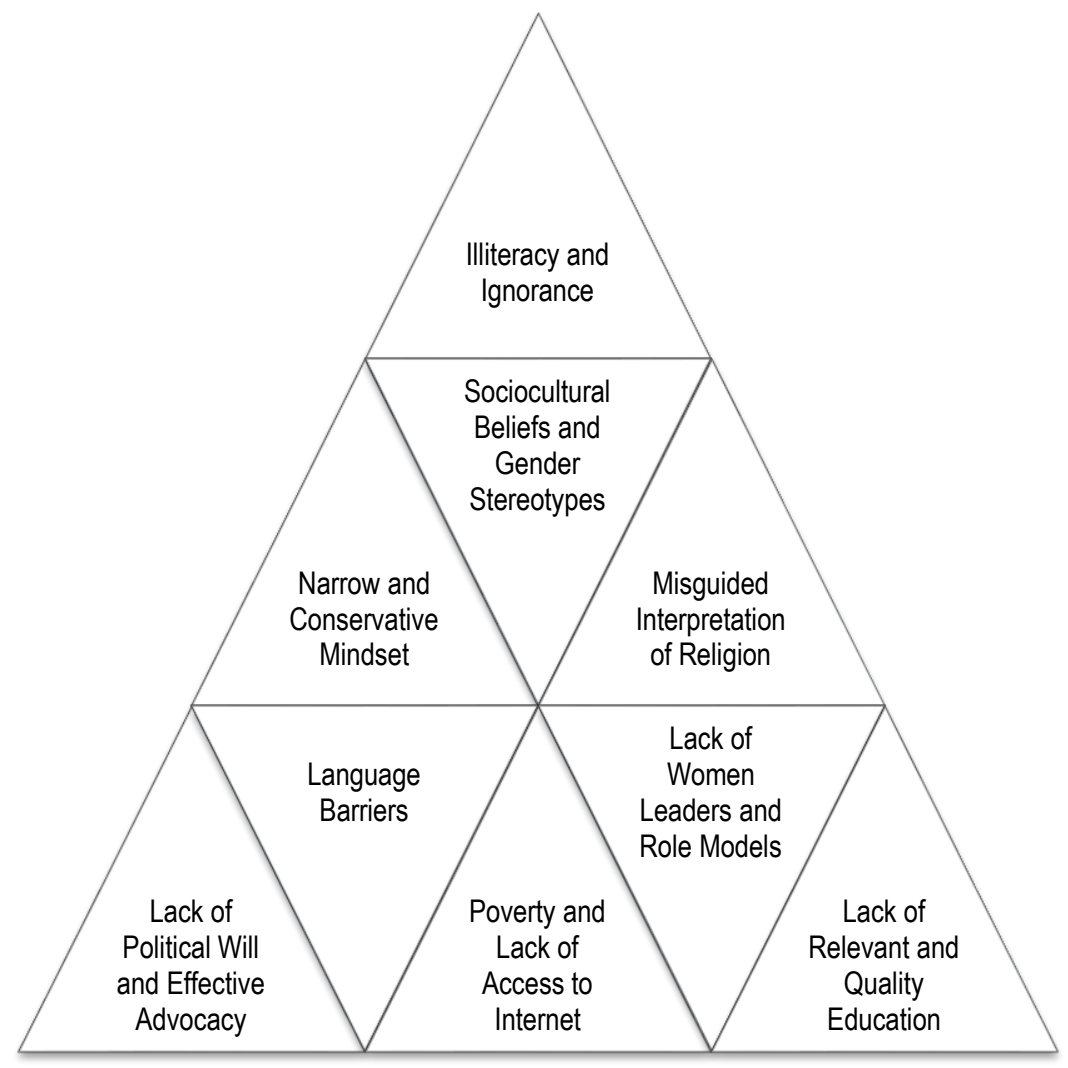

Figure 2. Factors Responsible for the Lack of Awareness About the Importance of Educating Girls 
Figure 3 summarizes the strategies to increase awareness about the importance of educating girls. The majority of study participants suggested active community engagement, strengthened civil society, targeted awareness campaigns, political will, and effective and affirmative action by the government and policy makers.

\title{
Targeted Awareness Campaigns
}

\section{Ongoing Counselling and Awareness}

Increase Awareness Through Socially Influential People, Celebrities, and Women Role Models

Effective Use of Social Media, Street Theatres, and TV Dramas

Effective Use of Technology: Mobile Apps, and Mobile and Internet Service Providers

Girls led Community Service, Social Clubs, Summer Projects, and Mentorship

Educating Religious Leaders and Community Elders; Gender Sensitization of Youth

\section{Active Community Engagement and Strengthening Civil Society \\ Political Will and Unwavering Commitment \\ Policy Reforms, Incentives, and Affirmative Action}

\author{
Training, Orientation, and Gender Sensitization of Teachers \\ Policy Advocacy \\ Gender Sensitive Curriculum, Textbooks, and Pedagogical Practices \\ Gender Mainstreaming and Women Empowerment \\ Involving Women in School Governance and Community Mobilization
}

Figure 3. Strategies to Increase Awareness About Importance of Educating Girls

\section{Importance and Impact of Educating Girls}

\section{Rights-Based Approach}

All participants agreed on the positive impact of educating girls. They were of the view that education is a fundamental right and there was no reason to deny girls this right. One male expert said, "Of course, it is important to educate girls, not because they are girls, but because they are human beings and all human beings ought to be given the right to pursue happiness and develop their potential." A female participant of the focus group narrated, "The world cannot only be run by men. Men and women are parallel to each other, one cannot function without the other."

\section{Human Capabilities Approach}

Educating a girl not only improves her life, but also the lives of her family, community and society at large. Denying girls their right to education, keeps many societies in the dark and at a disadvantage. A female expert said, "No country succeeds without educating its women." According to a male educator, "We no longer live in an era where the intellectual contributions of women and girls can be 
ignored or underrated." A male expert said, "Women have a particular way of looking at the world, which men cannot have. Then not educating them is impoverishing the society."

Not having an education greatly limits girls from participating in many activities which could benefit wider society; education enables her to contribute innovative ideas. A female expert said,

Girls' reduced access to education creates a cycle of reduced development across a society and across generations. Without equal access to education, a woman is denied a path towards her full potential. This then ripples beyond her personally, whereby families and communities are similarly deprived of their full capacity - economically and socially.

Additionally, a male educator stated, "Girls' education is a powerful tool to change perceptions and belief systems. Families with educated girls have a broader outlook towards society. Secondly, since girls are better communicators, they can easily influence and inspire the wider community."

Education enables girls to be confident, independent, earn self-respect in the society, and unleash their full potential. It allows them the ability to pursue their desired dreams and professional careers, and be recognized through what they do. It increases the work force and maximizes productivity, given the fact that girls constitute half of the world's population-although this only represent $10 \%-12 \%$ of the entire work force. A male expert explained,

If they are educated, they will have a profession. If they bring home some income, the whole family, particularly the joint families of South Asia and Africa, will respect this woman much more than if she was just a housewife and taking care of her family and children.

Education provides relevant knowledge and skills for girls to better understand and deal with life challenges. Education involves social interaction, which not only allows girls to feel that they are not alone, but also to feel well-supported by their peers and teachers/educators. Educated girls tend to marry at an appropriate age, eventually decreasing the number of child marriages and health problems. With increased health education, they are able to take better care of their families' health and well-being. As expressed by a male expert, "If you educate a female who becomes a mother, you educate an entire household, you lower the child mortality rates and you raise the economic earning potential too with healthier and more (economically) productive family members." A female development professional said, "If they (girls) are educated, they will have better understanding of nutrition, hygiene, and upbringing of their children. A child born to an educated mother is much more likely to survive past the age of five."

Many parents and teachers/educators claim that a mother is a child's first teacher and that an educated mother will be able to raise better educated children. If a girl is educated, she will transfer that knowledge and values to all those around her resulting in a positive ripple effect. As described by a male student, "Educating a girl is similar to educating an entire nation."

Educated girls tend to become role models and inspire others to pursue education. Education gives them the ability to positively influence their lives and the lives of their families and wider communities. Educated women tend to take leadership roles, especially within the community and focus on societal development. Education enables them to use sound judgement, empowers them, and strengthens their voice in society. A female expert said, "As they grow in confidence they can become community leaders and play an active role in the development of society."

In summary, educating girls is critical for the development of communities and broadly for society as a whole. Education is the most sustainable way to address global challenges like poverty, health issues, ignorance, lack of tolerance and conflicts, among others. As a male expert summarized, "It is absolutely important to educate girls. Eastern philosophy says-while with one hand a woman will 
shake the cradle, with the other hand she would change the world!" Another male expert said, "It is widely acknowledged that investments in the health, education and employment of young people, particularly adolescent girls, are among the most cost-effective development expenditures that may be undertaken."

\section{Awareness About Importance of Educating Girls and Proposed Strategies to Increase Awareness}

Participants acknowledged that the same level of awareness may not be required in North America, Europe, and Central Asia; however, concerted and targeted efforts are required in South and West Asia, Sub-Saharan Africa, Eastern Africa, the Middle East, and other developing regions with higher levels of gender disparity. It is important to enlighten communities on the importance of educating girls and the benefits to the community as a whole. Increased awareness will enable communities to gradually remove their reluctance to educate girls and will assist them in challenging and changing conservative social norms and stereotypes. As part of the study, the participants shared a variety of strategies, which are summarized below.

One participant suggested summer projects where girls are able to apply their learning on community issues and demonstrate the positive impact of their education. Another suggestion was to introduce mandatory community service and girl-led social clubs in all schools, which can facilitate social development and create awareness of various developmental challenges.

Mentorship programs may also be helpful, in which educated girls support other girls within the community to develop their potential and provide inspiration and encouragement. Another suggestion was for governments to campaign for girls' education, similar to former first lady of the United States Michelle Obama's Let Girls Learn initiative. The government's support and involvement of such personalities provides credibility and encouragement for others. It may be beneficial to use existing women leaders, female students, and celebrities for such awareness campaigns to inspire others.

Teachers and educators can be trained to increase their self-awareness on this subject and to educate existing learners, including boys, about gender disparities and the importance of educating girls. These learners may then create further awareness through educating their families and communities.

Some participants outlined the need for active community engagement and participation through parent-teacher associations, community and parental participation in school and educational governance, community and village development organizations, and community discussion forums, among others. It is very important to proactively engage community leaders, particularly male members. Such open discussions will assist in eliminating their reluctance to discuss such issues, which often involve conservative social norms and stereotypes. Once people start exploring and questioning, they will gradually realize the importance and will positively and actively contribute toward reducing gender disparity. As noted by a female expert, "Raising awareness is a slow process, and it is only the first step in bringing about change. True changes will come when awareness raising can tap into actual behavior change within families and communities." In terms of media, it is important to clearly demonstrate the impact with real examples and role models to inspire others. People are looking for real outcomes and impact as opposed to feel-good stories.

The type of audiences should be considered in selecting an appropriate choice of media: (a) Radio can be used to communicate with a less literate target audience; (b) mobile technology can be used in Africa and other places, where a large segment of the population has access to mobile phone; (c) in 
parts of South Asia, public transport system is also a common means of communication and marketing; and (d) TV and print media are excellent vehicles to target policy makers and government officials.

\section{Discussion}

The study framework stresses that (a) compulsory universal primary education should be regarded as a fundamental human right, (b) education is the right of each child so that she or he can grow to his or her full potential, and (c) there are significant socioeconomic benefits associated with receiving an education. Therefore, the strategies for achieving gender equality in education do not entail any unwelcome tradeoffs. On the contrary, achieving gender equality in education can deliver a wide range of associated benefits for the socioeconomic development of the society.

The study participants confirmed the importance of education and reiterated the positive effects of girls' education on the overall development of the society. However, an earlier study conducted in North Eastern Karnataka indicated that $70 \%$ of parent respondents mentioned that education is extremely important, but when it comes to girls' education, only 65\% responded affirmatively (Azim Premji Foundation, 2004). Another study that was conducted in Kenya reported that parents perceived that sending girls for education had no benefits and that they were only sending their girls for education due to government pressure (Bachar, 2012). The same study reported that fathers believe that, at the age of puberty, if girls continued school, they become spoiled and no man will marry them. The same study also went on to report parents' fear that educated girls will rebel and argue with them (Bachar, 2012).

This supports the finding from my study that, in the developing world, there is the need for greater awareness related to benefits of girls' education for individuals, family, and the community at large. One of the studies conducted in Kalomo, Zambia, indicated that parents' perception about girls' education is becoming increasingly positive; however, $43 \%$ parents are not completely in favor of educating girls because of the misunderstanding that girls are more vulnerable to early pregnancy by attending schools (Winason, 2011). A study conducted in Pakistan indicated that uneducated families living in urban areas also understand the importance of education (Jamal, 2014), which may be due to additional opportunities and resources that create an overall awareness in such settings.

The review of the earlier research studies cited above indicates the lack of awareness about the importance and impact of educating girls, particularly in remote and socioeconomically underprivileged communities. It reinforces the notion that lack of education and lack of socioeconomic development lead to lack of awareness about the importance of education, particularly girls' education. Contrary to some of these studies, the participants of the current study were educated professionals including educated parents and students currently enrolled in schools; therefore, their level of awareness is higher and their perception about the impact of educating girls is positive.

There is a need to decrease inequality in girls' education. Therefore, we need to increase awareness relating the importance of educating girls among parents, teachers/educators, community leaders, and the general community. If there is more awareness among society, there may be a greater possibility that more girls will be educated. Moreover, increasing access to girls' education and reducing gender disparities in education will result in increased numbers of people who not only achieve their basic human rights, but also go on to develop skills and abilities and work to support the overall society. This will also result in the opportunity to use their skills and talents and their capabilities and potentials to improve the lives of their families, society, and themselves (see Figure 4). 


\section{Increased awareness about the importance and impact of educating girls}

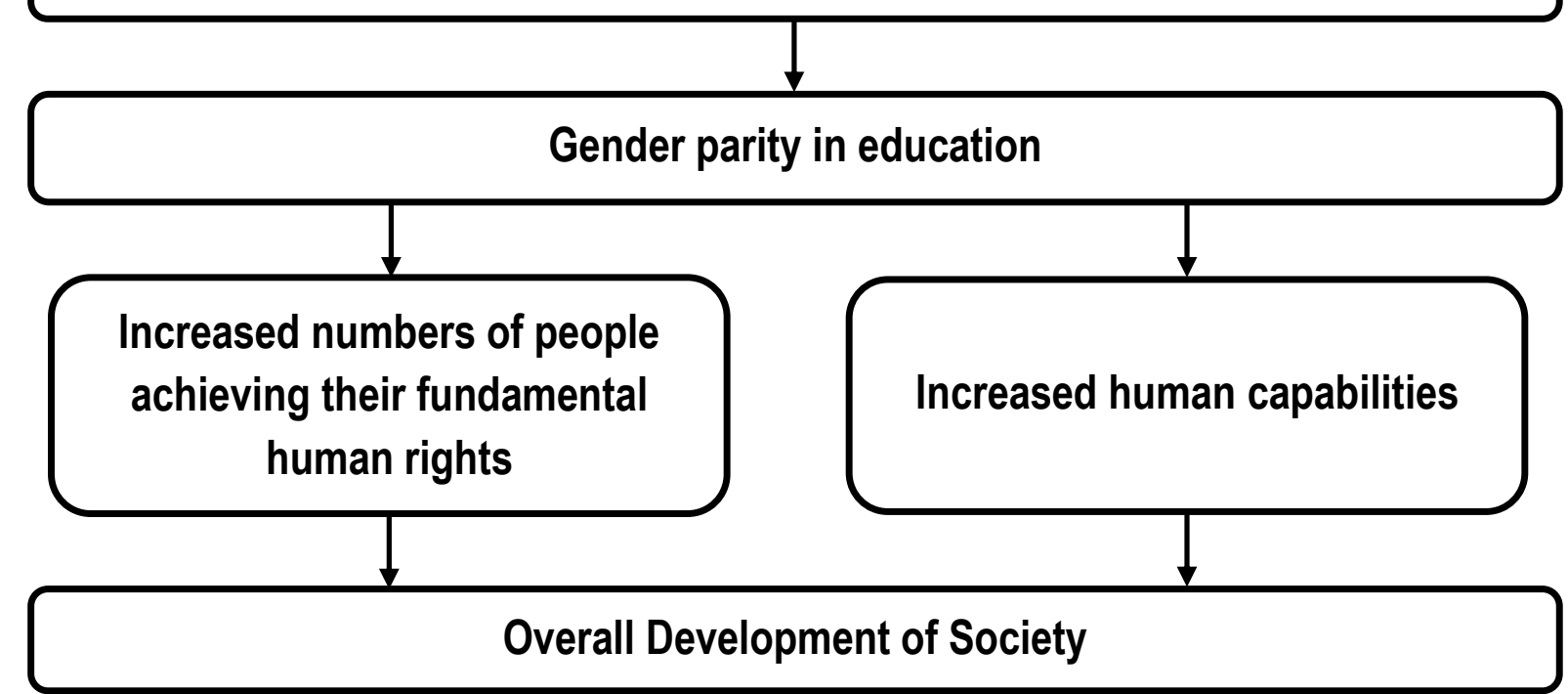

Figure 4. Study Framework for Societal Development

\section{Conclusion}

Education is a basic human right, and because females represent approximately half of the world's population - they form a significant global resource - their right to education cannot be ignored. "Imagine you are in a sinking boat. Half the people are knowledgeable on how to confront the issue while the other half is just seated, day dreaming," said a male student. This analogy emphasizes that educating boys and not educating girls' compromises the stability and development of the entire world. Therefore, it is critical to address gender disparity in education.

It is critical to empower women and to support them to eliminate gender disparity (UNICEF, 2015). Educating girls keeps hunger away, reduces the number of child marriages and early pregnancies, improves health status and overall socioeconomic circumstances, and creates a better and peaceful society (Bhagavatheeswaran et al., 2016; UNESCO, 2013). Education is one way through which we can disrupt the vicious circle of abuse, poverty, and oppression of women. Education empowers women, makes them aware of their rights, and enables them to maintain good health and raise healthy children and families. Education has a great influence on changing society (Khalid, 2012).

Given the current situation and socioeconomic circumstances, communities are required to make choices about sending their sons and daughters to school. Therefore, it is critical to increase awareness about the importance and impact of educating girls to enable communities to make appropriate choices and provide an enabling environment to achieve gender parity in education.

Creating awareness about the importance of educating girls and addressing the issue of gender disparity in education, require constant support from all stakeholders. Due to global scarcity of resources, it is vital to adopt a much more coordinated and integrated approach instead of duplicating efforts and working individually without adequate consultation or collaboration. It is also important to learn from previous experiences, initiatives, plans, and programs to analyze what worked and what did not work. 
This article makes a humble attempt by providing insight on the importance and impact of educating girls as well as proposing strategies to increase awareness. It is recommended to (a) institute longterm projects for more specific and impactful outcomes; (b) engage a wider range of stakeholders, particularly from target populations; (c) adopt a consultative and collaborative approach to project planning, implementation, and monitoring; and (d) effectively use social media to create awareness about the importance and impact of educating girls and to reduce gender disparity in education.

\section{References}

Andrés, A., \& Chavez, E. (2015). Which way out of poverty? The human capital versus human capabilities approaches. Maskana, 6, 19-25. Retrieved from http://uide.edu.ec/media/1401/maskana-6102.pdf

Azim Premji Foundation. (2004). Community perceptions on education: A study in north east Karnataka. Bangalore, India. Retrieved from http://righttoeducation.in/sites/default/files/CommonPercept.pdf

Bachar, M. (2012). The Maasai's perception of female education and Maasai girls' perception of their educational experiences in Kajiado (Master's thesis). Graduate School of Social Sciences, University of Amsterdam, Amsterdam, The Netherlands.

Bhagavatheeswaran, L., Nair, S., Stone, H., Isac, S., Hiremath, T., Raghavendra, T., ... Watts, C. (2016). The barriers and enablers to education among scheduled caste and scheduled tribe adolescent girls in northern Karnataka, South India: A qualitative study. International Journal of Educational Development, 49, 262-270.

Global Partnership for Education. (2016, March 10). Breaking down the barriers to girls' education. Retrieved from http://www.globalpartnership.org/multimedia/infographic/breaking-downbarriers-girls-education

Green, J., \& Thorogood, N. (2004). Qualitative methods for health research. London, United Kingdom: Sage Publications.

International Commission on Financing Global Education Opportunity. (2015). The learning generation: Investing in education for a changing world. Retrieved from http://report.educationcommission.org/wpcontent/uploads/2016/09/Learning_Generation_Full_Report.pdf

Jamal, A. (2014). Men's perception of women's role and girls' education among Pashtun tribes of Pakistan: A qualitative Delphi study. Cultural and Pedagogical Inquiry, 6, 17-34.

Jones, S. K. (2011). Girls' secondary education in Uganda: Assessing policy within the women's empowerment framework. Gender and Education, 23, 385-413.

Khalid, W. (2012, April 28). Lack of education is adversely affecting girls. Pakistan Today. Retrieved from https://www.pakistantoday.com.pk/2012/04/28/lack-of-education-is-adversely-affectinggirls/

Savin-Baden, M., \& Major, C. H. (2013). Qualitative research: The essential guide to theory and practice. Abingdon, United Kingdom: Routledge.

Sen, A. (1997). Human capital and human capability. World Development, 25, 1959-1961.

Somani, T. (2017). Girls have a right to education too. Unpublished report, Senior School, Aga Khan Academy, Mombasa, Mombasa, Kenya.

Suen, S. (2013). The education of women as a tool in development: challenging the African maxim. Hydra, 1, 60-76. 
United Nations (UN). (2000). News on millennium development goals. Retrieved from http://www.un.org/millenniumgoals/

United Nations Children's Fund (UNICEF). (2007). A human rights-based approach to education for all. Retrieved from

https://www.unicef.org/publications/files/A_Human_Rights_Based_Approach_to_Education_f or_All.pdf

United Nations Children's Fund (UNICEF). (2015, July 23). Girls' education and gender equality. Retrieved January 10, 2017, from http://www.unicef.org/education/bege_70640.html

United Nations (UN) Development Programme. (1995). Human development report. New York, NY: Oxford University Press.

United Nations (UN) Development Programme. (2015). Sustainable development goals. Retrieved from http://www.undp.org/content/undp/en/home/sustainable-development-goals.html

United Nations Education, Scientific, and Cultural Organization (UNESCO). (1990). World declaration on education for all and framework for action to meet basic learning needs. Jomtien, Thailand: Author.

United Nations Educational, Scientific, and Cultural Organization (UNESCO). (2000a). Conference report: Asia-Pacific conference on education for all 2000 assessment. Bangkok, Thailand: Author.

United Nations Educational, Scientific, and Cultural Organization (UNESCO). (2000b). The Dakar framework for action: Education for all. Paris, France: Author.

United Nations Educational, Scientific, and Cultural Organization (UNESCO). (2013). Girls' education: The facts. Retrieved from http://en.unesco.org/gem-report/sites/gemreport/files/girls-factsheet-en.pdf

United Nations Educational, Scientific, and Cultural Organization (UNESCO). (2014). Girls' and women's right to education: Overview of the measures supporting the right to education for girls and women reported on by member states. Paris, France: Author.

United Nations Educational, Scientific, and Cultural Organization (UNESCO). (2016). Global education monitoring report: Education for people and planet: Creating sustainable futures for all. Paris, France: Author.

United Nations Educational, Scientific, and Cultural Organization (UNESCO) Institute for Statistics. (2016). eAtlas of gender inequality in education. Retrieved from http://www.tellmaps.com/uis/gender/

United Nations (UN) General Assembly. (1948). Universal declaration of human rights (217 [III] AArticle 26). Paris, France: Author. Retrieved from http://www.un.org/en/universaldeclaration-human-rights/

United Nations (UN) General Assembly. (1979). Convention on the elimination of all forms of discrimination against women (Session 34, Resolution 180). New York, NY: Author. Retrieved from http://www.ohchr.org/EN/ProfessionalInterest/Pages/CEDAW.aspx

United Nations (UN) General Assembly. (1989). Convention on the rights of the child (Session 44, Resolution 25). Retrieved from http://www.ohchr.org/EN/ProfessionalInterest/Pages/CRC.aspx

Winason, M. (2011). An evaluation study on societal perception of girl-child education: A case study of Kaganga Area in Kalomo. Retrieved from http://dspace.unza.zm:8080/xmlui/bitstream/handle/123456789/1085/maliko.pdf?sequ\%20enc $\mathrm{e}=1 \&$ isAllowed $=\mathrm{y}$ 
The Journal of Educational Research and Practice provides a forum for studies and dialogue that allows readers to better develop social change in the field of education and learning. Journal content may focus on educational issues of all ages and in all settings. It also presents peer-reviewed commentaries, book reviews, interviews of prominent individuals, and additional content. The objectives: We publish research and related content that examines current relevant educational issues and processes aimed at presenting readers with knowledge and showing how that knowledge can be used to impact social change in educational or learning environments. Additional content provides an opportunity for scholarly and professional dialogue regarding that content's usefulness in expanding the body of scholarly knowledge and increasing readers' effectiveness as educators. The journal also focuses on facilitating the activities of both researcher-practitioners and practitioner-researchers, providing optimal opportunities for interdisciplinary and collaborative thought through blogging and other communications.

Walden University Publishing: http://www.publishing.waldenu.edu 